\title{
Article \\ Outsiders Within: Framing and Regulation of Headscarves in France, Germany and The Netherlands
}

\author{
Doutje Lettinga and Sawitri Saharso * \\ Department of Public Administration, University of Twente, Postbox 217, 7500AE Enschede, The Netherlands; \\ E-Mails: doutjelettinga@gmail.com (D.L.), s.saharso@utwente.nl (S.S.); Tel.: +31-534893268 (S.S.) \\ * Corresponding author
}

Submitted: 1 April 2014 | In Revised Form: 1 July 2014 | Accepted: 9 July 2014 | Published: 17 September 2014

\begin{abstract}
While women in Europe who wear the Islamic headscarf are generally seen as outsiders who do not belong to the nation, some countries are more tolerant towards the wearing of headscarves than others. France, Germany and the Netherlands have developed different policies regarding veiling. In this paper we describe how headscarves became regulated in each of these countries and discuss the ways in which French, Dutch and German politicians have deliberated the issue. The paper is based on a content analysis of parliamentary debates on veiling in France (1989-2007), Germany (1997-2007) and the Netherlands (1985-2007). Our aim is to discuss what these national political debates reveal about the way in which the social inclusion of Islamic women in (or rather exclusion from) the nation is perceived in these three countries. Our claim is that veiling arouses opposition because it challenges national self-understandings. Yet, because nations have different histories of nation building, these self-understandings are challenged in various ways and hence, governments have responded to headscarves with diverse regulation. While we did find national differences, we also discovered that the political debates in the three countries are converging over time. The trend is towards increasingly gendered debates and more restrictive headscarf policies. This, we hypothesize, is explained by international polarization around Islam and the strength of the populist anti-immigrant parties across Europe.
\end{abstract}

\section{Keywords}

citizenship; gender relations; headscarf; Islam; migration; multiculturalism; state-church relations; veil

\section{Issue}

This article is part of the special issue "Policing Ethnicity: Between the Rhetoric of Inclusion and the Practices and Policies of Exclusion", edited by Professor Abby Peterson (University of Gothenburg, Sweden) and Professor Malin Åkerström (University of Lund, Sweden).

(C) 2014 by the authors; licensee Cogitatio (Lisbon, Portugal). This article is licensed under a Creative Commons Attribution 4.0 International License (CC BY).

\section{Introduction}

The Islamic headscarf has become a contested issue in Europe. ${ }^{1}$ Yet while some countries have issued bans, others explicitly grant women the right to wear a head-

1 There exist many forms of Muslim women's covering. The main distinctions are between the headscarf and the burqa and niqab. The burqa covers the face including the eyes, while the niqab leaves free the eyes. In the time-period we studied the debates focused mainly on the headscarf. scarf, and still others have no regulation at all. In this paper we discuss the framing and regulation of the headscarf in three countries: the Netherlands, Germany and France. These countries are believed to represent different citizenship and state-church models. We did find national differences in the framing and regulation of the headscarf and wanted to discover whether these can be attributed to these models. Yet across countries, headscarves increasingly became framed as contravening dominant gender notions. Therefore we considered also the role of the (institutionalized) wom- 
en's movement in the national debates. We found in all three countries that occasionally there were actors who contested the dominant framing and who proposed a more inclusive idea of national identity.

We followed an inductive approach: as laws are made in parliament we made a content analysis of parliamentary debates on the headscarf in France (19892007), Germany (1997-2007) and the Netherlands (1985-2007). In 1985 the issue of the headscarf appeared for the first time on the political agenda in the Netherlands. We extended the period to 2007 to be able to trace possible effects of watershed political events like 9/11. The debates after 2007 were analyzed less systematically. ${ }^{2}$ We looked at the arguments that were given by actors in Parliament for the regulation or non-regulation of the headscarf, and what these arguments tell us about the way that the social inclusion of Islamic women in (or rather exclusion from) the nation was conceived. We also traced the influence of important legal court rulings or legal advice on the framing and regulating of the headscarf.

We will first explain the notion of national citizenship and state-church models. Then we explain our methodology and present per country the way the headscarf is regulated and how this was argued in Parliament. In the conclusion we come back to the question of whether or not national models of citizenship and state-church relations explain the regulation of the headscarf in each of the three countries, and what this framing tells us about the social inclusion of Islamic women.

\section{National Models of Citizenship and State-Church Relations}

The idea of national citizenship models impacting the social inclusion of immigrants can be traced back to Rogers Brubaker's study on citizenship and nationhood in France and Germany (Brubaker, 1992). The thrust of his argument is that when in the $19^{\text {th }}$ century the French and German state was formed, there evolved in both countries a nation-specific understanding of nationhood. Once established, these understandings proved to have path-dependent effects on these countries' presentday immigration and citizenship policies. Several authors (e.g. Castles, 1995; Koopmans et al., 2005) followed up this idea and suggested that it is these very traditions of citizenship that explain why countries differ in the extent to which they are open to accommodate cultural difference. France, Germany and the Netherlands would represent respectively a republican, an ethno-cultural and multicultural model.

In order to explain country responses to the integration of Muslim immigrants in particular, several theorists have also included state-church relations as

2 A major change is that after 2007 the emphasis shifted to face-veiling. See Ferrari and Pastorelli (2013). an explanatory variable (Fetzer \& Soper, 2005; Foblets \& Alidadi, 2013; Koenig, 2007; Modood \& Kastoryano, 2006). In this literature, France is seen as a prototypical example of a strict church-state separation model. State neutrality is assumed to be best achieved through a hands-off approach to religion: the state should not identify with any religion nor prioritize any religious group over another, and abstain from recognizing and funding religious groups. The Netherlands figures as an ideal-typical example of a pluralist model. Here state neutrality is achieved not by banning religion from public life, but by treating all religious and secular worldviews in an evenhanded way. Germany is typically characterized as a pluralistic corporatist model. Based on agreements (concordats) between the state and the church the two officially cooperate. In this paper, we understand state-church relations to serve as key parts of countries' conceptions of nationhood, because the legal and political status of religion is inherently intertwined with a nation's social organization and construction (Asad, 2006; Koenig, 2007).

In the republican-secularist model the nation is conceived of as an undivided community of citizens that share common political principles. The state is a strong, centralized body that stands above its citizens. In order to secure common citizenship, citizens are asked to abstract from their particularistic identities and exist in the public sphere as citizens only. Anyone who is willing to subscribe to the nation's principles can in theory become a citizen. This model is therefore open to accept immigrants as citizens, but they are expected to assimilate in one uniform nation and to avoid pubic expressions of their personal religious affiliations. And indeed in France immigrants have easy access to citizenship, yet assimilation to 'French' universal values like equality and liberty is required. While the state takes a hands-off approach to religious doctrine, it simultaneously officially recognizes Islam as 'cultes' (organised religions, not communities) similar to Catholic, Lutheran and Calvinist religions. Since 2002 it has recognised the French Muslim Council ('Conseil Français du Culte Musulman', CFCM) as an official interlocutor comparable to the Catholic, Jewish and Protestant religious councils (Laborde, 2008).

An ethno-cultural corporatist model conceives of the nation as a culturally homogeneous community. The nation is considered as the political extension of an already existing ethnic community based on a common history, culture and language. Because of its cultural monism, it has difficulty both in accepting cultural aliens as citizens and in allowing for any other than the dominant majority's culture in public life. Indeed Germany long excluded non-ethnically German migrants from citizenship and did not grant them cultural rights. Germany's church-state relations still institutionally favour historically dominant Christian churches with whom the state cooperates in sectors such as educa- 
tion, health and social welfare. Only the three main historical religious communities (Catholic, Evangelical and Jewish) are granted legal status as public corporations, which yields them specific privileges. Länder Governments have thus far refused to grant Islam the status of an officially recognised religion and public body.

Lastly, in a multicultural pluralist model, the nation is united by a thin core of common values, which goes together with the co-existence of groups that have their distinctive group identities. A multicultural model is open to accept immigrants as citizens and is open to cultural diversity. The Netherlands used to combine easy access to citizenship with a policy of integration based on the preservation of cultural group identities, and its state-church model ensures equal treatment of all religious groups, including Muslim groups, and equal access to the public sphere. Unlike France, the state does not attempt to secularise the public sphere; unlike Germany, it does not grant any public status to and cuts all financial ties with organised religions.

From these models one would expect France and Germany, yet for different reasons, to be less open to cultural and religious manifestations of migrants and to restrict the wearing of the headscarf, and the Netherlands to have accommodative regulation. Although German state-church relations offer favourable opportunities for the public expression of religion, the lack of public status of Islam in Germany makes us expect that Muslim communities benefit less from these opportunities than in the Netherlands.

However, the idea of national citizenship models explaining modes of integration has become contested. ${ }^{3}$ European policies on immigrant integration appear according to Christian Joppke (2007) to converge. Comparing civic integration tests in five countries, including our three countries, Ines Michalowski (2011) and Saskia Bonjour (2010) find national differences that do not correspond with the national citizenship models. Noticing a widespread backlash against multiculturalism, Stephen Castles and Mark Miller doubt whether the multicultural model still exists in Europe (Castles \& Miller, 2011). In sum, critics maintain that citizenship models are too deterministic and too static, as they cannot explain changes over time within a country or convergences between countries. Are national models indeed passé? After explaining our methodology, we turn to the regulation of the headscarf and the debates that accompanied the introduction of the rules.

\section{Methodology}

The main documents that were studied for this article consist of all parliamentary debates about headscarves in Germany, France and the Netherland, from the mo- ment the first public controversy arose (that was in the Netherlands in 1985) until 2007. All documents were found in the parliamentary databases of each country by means of keywords such as 'foulard', 'hidjeb', 'voile islamique', 'hoofddoek', 'Kopftuch', 'Schleier'. ${ }^{4}$ As Germany has a federal system and the issue was hardly discussed at the federal level (the 'Bundesrat'), we turned to the regional level. As it was not possible to study the debates in all sixteen states, documents were retrieved from the parliamentary databases of four federal states: Baden-Württemberg, Berlin, SchleswigHolstein and Rhineland-Palatinate. In total 192 law proposals, motions, parliamentary discussion, questions and policy documents were found, which were completed by other policy documents such as research reports of (extra) parliamentary committees, as well as a study of important court verdicts and decisions of (quasi) judicial bodies on individual headscarf conflicts.

We used frame-analysis to analyze the documents, which builds upon the social constructionist tradition in the social sciences that assumes that people construct realities by the way they think and talk about phenomena (Schön \& Rein, 1995; Verloo, 2005). Frames are thus symbolic-interpretive constructs used to make sense of a multifaceted issue such as the headscarf conflict, which at the same time shape reality by inscribing meaning to it. In order to identify the frames, we employed an analytical framework that exists of sensitizing questions focused on four elements (Verloo, 2005): voice (who speaks), diagnosis (what is seen as a problem), prognosis (what is seen as the solution) and a call for action (who is called upon to act upon the problem). All documents were coded according to these four elements of the matrix. Based on a comparison of these matrixes, three major frame-categories were found that were further divided in sub-frames: frames that addressed headscarves in relation to statechurch relations, frames that discuss headscarves in relation to social cohesion and/or public order and frames that discuss headscarves in relation to gender (see Lettinga 2011 for more on the methodology used).

\footnotetext{
${ }^{4}$ The Dutch databases were: www.statengeneraaldigitaal.nl and www.parlando.sdu.nl. For France we visited: www.assem blee-nationale.fr (from 1993). Documents from before 1993 were collected manually in the archives of the Parliament in Paris. Documents from the French Senate were retrieved from www.senat.fr. For Germany we visited www.dip.bundestag.de. The federal states have their own online databases; documents that were not online we collected from the archives. An explanatory note on the references: TK $59=$ Tweede Kamer (Dutch Second Chamber), Parliamentary Report nr. 59. JO 15577 = Journal Officiel de la Republique Française, Parliamentary Report nr. 15577. BW 13/62 = digital archive of the Parliament of Baden Württemberg, Parliamentary Report nr. $13 / 62$. RP $=$ Rhineland Palatinate. $B=$ Berlin. All documents are followed by the date and when necessary the page number.
}

${ }^{3}$ See for an early critique Silverman (1992). 


\section{France: Framing and Regulation of the Headscarf}

As widely reported elsewhere (Bowen, 2007; Rochefort, 2002; Scott, 2007) the debate in France started in 1989 when three schoolgirls in the city of Creil were not allowed to wear a headscarf at school. The school principal argued that the headscarf could yield pressure on others to cover against their will. After seeking advice of the State Council (Conseil d'Etat), the highest administrative court of France, the Socialist Minister of Education, Lionel Jospin, ruled that students wearing signs of religious affiliation in public schools was not necessarily in conflict with public neutrality (laïcité), as long as they did not disturb the educational order in schools or seek to proselytize their religion. ${ }^{5}$ Three weeks later, the Socialist government issued a Directive to schools encouraging them to take a case-by-case approach in assessing whether the religious manifestation in question was expressed within the confines of this neutrality, and to discuss the issue before expelling pupils. ${ }^{6}$

Not all parties felt comfortable with the Minister's decision. Among them was the Rassemblement pour la République (RPR), which framed the headscarf as an act of provocation of the French Republican pact, signifying a segregation from the rest of society (a 'repli communitaire') and a politicized symbol of religious fundamentalism ('intégrisme') challenging the secular and democratic state. ${ }^{7}$ From the onset of the debate, both the Left and the Right agreed that the headscarf conflicted with principles of gender equality. Both viewed the Republican school as a motor for girls' emancipation by providing them with the tools to break with their patriarchal community and to integrate into 'French' society. As RPR-member Michèle Barzach argued: 'The integration of the Muslim population passes through its women, and the integration of women passes through schools'. ${ }^{8}$ Yet, while the RPR concluded that headscarves should therefore be banned from public schools, prominent members of the Socialist party argued that a ban was counterproductive. Prime-minister Michel Rocard (PS) explained: 'The aim of our public and laic school is to welcome, to persuade, to integrate, that means, to realize the goals of education in another way than through a politics of a priori exclusion'. ${ }^{9}$ Therefore a ban on headscarves was unwarranted.

After the turn of the century the Socialist party (PS) changed its position. Instead of the gradual assimilation they had expected, headscarf conflicts kept emerging in public schools throughout the 1990s. In 2003, some PS members submitted a proposal to ban all religious, political and philosophic symbols from school, framing the

\footnotetext{
5 JO 346 893, 27 November 1989.

6 JO 15577, 15 November 1989.

7 JO 4756-4757, 8 November 1989.

8 JO 4756-4757, 8 November 1989.

9 JO 4751-4752, 8 November 1989.
}

headscarf as a 'contestation of French values and culture', and 'a rejection, often imposed on young girls, of the Republican and laic model of integration'. ${ }^{10}$ Also the Right submitted (again) several proposals to ban religious dress in public schools. In July 2003, President Jacques Chirac installed the Commission of Reflection on the Application of the Principle of Laïcité in the Republic' ('Commission de réflexion sur l'application du principe de laïcité dans la République') to study the status of secularism in present-day France. This commission, known as the Commission Stasi, concluded that a ban was needed (Stasi, 2003). On 10 February 2004, a large majority in parliament voted in favour of a government lawproposal for a ban on 'ostentatious' religious symbols in the public school. On 15 March 2004, the French government passed the law that came into effect the subsequent school year. The Ministry of Educations sent a Directive to all public schools that explained that headscarves, kippahs and large Christian crosses are considered as conspicuous signs of religious affiliation, and are prohibited.

This change went together with a change in diagnosis. Before, girls who wore a headscarf were seen as girls who needed to be emancipated; now attention focused on girls who did not wear the headscarf and who needed to be protected against their communities. The actions of the new feminist movement, Neither Whores nor Submissives ('Ni Putes Ni Soumises', NPNS), may have contributed to this change in framing. The chair of NPNS, Fadela Amara, who later became a Socialist Junior Minister, spoke out in favor of legislation banning headscarves in schools. Together with other prominent Republican feminists, among others Elisabeth Badinter, Anne Zelensky (the chair of the League of Women's Rights, LDF) and former Minister of Emancipation Yvette Roudy, NPNS signed a petition in Elle magazine in 2003 to encourage French President Jacques Chirac to impose a ban. Amara was also invited by the Stasi commission to testify, and the commission literally copied in its report her testimony that many young girls were called 'whores' if they did not cover (Stasi, 2003, p. 46). The commission concluded that a 'great silent majority' of young girls of immigrant origin needed protection against Islamist groups forcing them to cover (Stasi, 2003, p. 58). The struggle for gender equality subsequently became a struggle for national values, as is illustrated by the speech of President Chirac, who stated that 'our struggle for Republican values must go hand in hand with a struggle for women's rights and their equality to men. This struggle will determine the France of tomorrow. The degree of civilization of a society is measured (...) by the status of women in that society' (Chirac, 2003).

The lack of headscarf-wearing girls' own voices in French public and policy debates triggered the mobili-

10 JO law proposal 2096, 2003. 
sation of new feminist coalitions seeking to break the hegemonic frame that headscarf-wearing girls were oppressed, for example Feminists For Equality ('Collectif des Féministes pour l'Egalité', CFE) that published a book in 2008 named 'Veiled girls speak' (Chouder, Latreche, \& Tévanian, 2008). Others were the Parisian group, Neither Pimps nor Machos ('Ni Proxos Ni Machos, NPNM) that challenged the view that Muslim men were violent, and the 'Movement of Indigenous of the Republic' ('Mouvement des Indigènes de la Republique', MIR) that argued that the 2003 law was a new form of post-colonialism, racism and sexism of a Republic which subjugated migrants to secondary subjects (Bouteldja, 2007). Yet, not being invited to official policy consultations and unable to forge alliances except for a few among the far left, they did not have the power to change the dominant discourse.

The French debate on the headscarf did not carry over to other realms such as to the civil service or the judiciary. This is not indicative of a general tolerance of religious dress in other public domains. Rather, deputies never challenged the State Council's opinion of May 3, 2000, that civil servants, including school teachers and school inspectors, may not manifest their religious beliefs during work. ${ }^{11}$ Since 2009 the debate has shifted to the Islamic face veil, which was primarily framed as symbolising a radical Islamic practice that discriminated against women. On 22 June 2009 President Nicolas Sarkozy concurred with this view, arguing in a speech to the Senate and the Assembly at the Congress of Versailles: 'The burqa is not a sign of religion, it is a sign of subservience. It will not be welcome on the territory of the French republic' (Sarkozy, 2009). One year later, in September 2010, the Parliament adopted a law that bans all kinds of face covers in public spaces, which took effect in April 2011. ${ }^{12}$ The face veil was seen as an attack on the French Republican social pact of living together and human dignity, including gender equality and liberty. The law was passed despite the advise of the State Council and a parliamentary Commission of Inquiry that had both argued that there is no legal ground to oblige citizens to always show their faces (Joppke, 2001).

\section{The Netherlands: Framing and Regulation of the Headscarf}

In the Netherlands a national controversy arose in 1985 when a public school prohibited a pupil from wearing a headscarf. Members of Parliament chal-

\footnotetext{
11 JO 217.017, 3 May 2000.

12 Veiled women will be consulted by organisations with the aim to convince them to reconsider their choice within six months after their first arrest, and can be fined if they repeatedly ignore warnings of the police to unveil in public. People found guilty of forcing others to cover are penalised with fines up to $€ 30.000$ and a year in prison.
}

lenged this decision, and the Christian Democratic Minister of Education, Wim Deetman, announced that headscarves are allowed at public schools in the Netherlands. ${ }^{13}$ More than a decade later, in 1998, the issue re-emerged on the political agenda, this time because a teacher trainee was prohibited from wearing a headscarf in a public primary school. Again, the government decided, thereby following the legal advice of the Committee of Equal Treatment, ${ }^{14}$ that a ban on religious dress for public school teachers constitutes a form of discrimination on grounds of religion. Later again, two MP's of the Green Party brought up the issue of a woman who was not allowed to wear her headscarf while working as the clerk of a court. The Green party disputed the idea that headscarves in court were at odds with public neutrality. The Dutch understanding of the separation between church and state was, according to the Greens, not 'to exclude clergymen and religious traditions or signs from public life. (...) It means exactly the opposite: the state has no right to interfere with the religious beliefs of its subjects' ${ }^{15}$ The Liberal Minister of Justice Korthals disagreed that personnel in court could wear a headscarf and the court case eventually led to the policy report, Fundamental Rights in a Pluriform Society ('Grondrechten in een pluriforme samenleving'). ${ }^{16}$ In this document the government recognized that a ban infringes upon the principle of individual choice, which the Dutch state holds in high esteem (and thus went a long way towards the position of the Greens): 'The freedom of choice and right to self-determination that women in the Netherlands conquered holds equally for them (i.e. Muslim women). (...) A general ban on such cloths conflicts with this conquered freedom. (...) Also women with headscarves have the right to unlimited participation in Dutch society. ${ }^{17}$ While the government confirmed the right of women to wear a headscarf, it made two exceptions. It did consider it legitimate to restrict this right for the police force and for the judiciary because these jobs require, according to the government, that all appearance of partiality is avoided. ${ }^{18}$ Again in 2008 when a new debate about headscarves in the police force flared up, this policy was re-confirmed. ${ }^{19}$

Hence, even in the Netherlands the wearing of the headscarf became bound to some restrictions. This coincided with the rise of the new populist party, List Pim Fortuyn (Lijst Pim Fortuyn, LPF). The LPF became the second largest party in the elections of 2002 and had started a campaign against the 'Islamization of Dutch

\footnotetext{
${ }_{13}$ TK 700, 8 February 1985.

${ }^{14}$ Equal Treatment Committee Judgement 18 (1999).

15 TK 59, 17 March 2004: 3887.

${ }^{16}$ TK 29614, no. 2, 7 June 2004.

17 TK 29614, no. 2, 7 June 2004: 14-15.

18 TK 29614, no. 2, 7 June 2004.

19 TK 29628, no. 109, 14 November 2008.
} 
society'. The framing of Islam as a threat began resonating particularly when the debate shifted to face covers (burqas and niqabs). In a debate about terrorism in 2005, right-wing politician Geert Wilders introduced a motion to ban the burqa in public space. ${ }^{20} \mathrm{~A}$ majority in parliament adopted Wilders' motion. ${ }^{2122}$ Face covering was framed mainly as a security and integration issue. Liberal (VVD) MP Weekers argued, for instance: 'When people cover their face in public, whether this is with a burqa or with a balaclava, this seriously affects other people's feelings of safety, and the care for a civil public order implies that we do not tolerate such face covers' ${ }^{23}$ Parallel to this new emphasis on public order and security, gender equality became a more prominent frame. Both conservative Liberal and populist right-wing deputies argued that 'the burqa is a symbol of submission. This does not fit into our value-system' (VVD). ${ }^{24}$ Left-wing parties and the Liberal Democrats (D'66) agreed that face covers are incompatible with an 'open and emancipated society'. ${ }^{25}$ Yet, instead of a ban they favoured to 'emancipate the burqa away'. ${ }^{26}$

The gendering of the debate was not a result of a greater involvement of the women's movement in the policy debates. The platform for black, migrant and refugee women, Tiye International, as well as the Dutch Women's Council (NVR) never addressed the issue of headscarves, which they generally perceive to be women's own choice. Only Chief Editor Ciska Dresselhuys of the feminist monthly Opzij agitated against the headscarf as a sign of female oppression. Even feminist Ayaan Hirsi Ali who entered Parliament in 2003 and who was very critical about Islam, never politicised headscarves in Parliament. Dutch feminists never mobilised for restrictive legislation on the headscarf or the face-veil. Even though there was more discontent with the gendered nature of the face-veil within the Dutch women's movement, feminists scholars in advisory committees and the Ministry argued that a full ban would possibly increase the isolation of women who wore a face-veil rather than contribute to their emancipation. ${ }^{27}$

20 TK 29754, no. 53, 13 October 2005.

21 TK 36, 10 December 2005.

22 TK 16, 24 October 2006.

${ }^{23}$ TK 15, 19 October 2006: 1073.

24 TK 15, 19 October 2006: 1073.

25 TK 31700 VII, 25 December 2008.

${ }^{26}$ TK 16, 24 October 2006.

27 See e.g. the advice of a committee that was installed by then Minister of Integration to study the feasibility and desirability of a ban on burqas (Vermeulen et al., 2006). The then State Secretary responsible for emancipation (and current Minister of Education) Jet Bussemaker ( $P v d A$ ) answered in a reply to members of the PVV in 2008 that the burqini (a bathing suit that covers the legs, arms and hair of women) is not necessarily oppressive and can even enable women to partake in public life and gain independence. TK 1938, 11 April 2008.

\section{Germany: Framing and Regulation of the Headscarf}

The first parliamentary debates in Germany occurred in the southern federal state of Baden-Württemberg in 1997, but only in 2003 the headscarf controversy became a national affair when it spread to other federal states. The debate primarily focused on teachers' rights to cover. In contrast to France and similar to the Netherlands, pupils' headscarves have never been controversial.

The case that triggered the first debate concerned Fereshta Ludin, a German teacher of Afghani origin. She had already worn a headscarf during her traineeship without any complaints from parents, but when she applied for a job as a teacher in 1998 in the city of Stuttgart, the Upper School Authority in Baden-Württemberg refused to hire her because of her headscarf. The argument was that the headscarf was a sign of 'cultural limitation' and that she therefore lacked the personal qualifications ('Eignung') for the status of a civil servant, who needs to respect state neutrality (Altinordu, 2004).

The Minister of Education of Baden-Württemberg, Annette Schavan of the Christian Democrats (CDU), backed the decision of the Upper School Authority. As a teacher, Ludin was expected to distance herself from political ideologies that are in conflict with the state's constitutional values; Schavan did not consider the headscarf as a religious obligation. ${ }^{28}$ Ludin's headscarf would also undermine the school's mission to promote integration, as the headscarf 'functioned as a sign of cultural and civilizational segregation and thus encourages disintegration'. ${ }^{29}$ Most parties in the Land's legislature, including the oppositional Greens and Social Democrat party, supported the Minister's decision.

Five years later, on 24 September 2003, the Federal Constitutional Court ruled over Ludin's case after a tardy legal battle through various lower courts and the Federal Administrative Court. The Federal Constitutional Court judged that a ban on teachers wearing the headscarf in school does not find enough legal ground in the standing law of the federal state of Baden-Württemberg. Allowing teachers to wear headscarves did not contradict Germany's tradition of neutrality, seen as 'open and comprehensive neutrality' ('offene und übergreifende Neutralität). Therefore the law did not contain sufficient provisions to justify the restriction (Henkes \& Kneip, 2008 , p. 13). The Court recognized however that given the religious diversity of present-day society, a teacher's headscarf could yield conflicts and thus endanger educational peace. It ruled therefore that the growing religious diversity in society 'can be a cause for the legislature to redefine the allowed range of religious relations in the school' and to interpret the duty of public neutrality in a

28 Pressemitteilung no. $119 / 98$ of Ministry of Culture, Sports and Youth, 13 July 1998.

${ }^{29}$ BW 12/51, 15 July 1998: 3984. 
'stricter and more distanced way'. ${ }^{30}$

Since then eight of Germany's sixteen federal states have passed laws forbidding public school teachers to wear religious symbols and clothing in school (Table 1). In two states the ban was extended to public servants in the field of justice, police and law-enforcement (Berlin and Hessen). In Baden-Württemberg and Berlin, legislation exists also for kindergarten personnel. The other eight states have no regulation and continue their caseby-case approach (Lettinga, 2011). Following Berghahn and Rostock (2009) we differentiate between three types of policy regimes that now exist in Germany: the Christian-Occidental model, the laic model and the caseby-case model.

\subsection{Christian Occidental Model}

Baden-Württemberg was the first state to enact legislation of the 'Christian-Occidental' type on 1 April 2004. Saarland, Hessen, Bavaria and North RhineWestphalia followed suit. These states' laws do not ban religious symbols for teachers per se, but symbols or clothing that endanger the peace at school or the neutrality of the state, or else conflict with the basic rights of parents and/or pupils, or with the 'free, democratic order' (or a combination of these). ${ }^{31}$ All five states have formulated exception clauses for symbols of 'ChristianOccidental' values. As the socialist party (SPD) fraction leader Peter Wintruff explained: 'Different from the

30 Urteil BVerfG, 2 BvR 1436/02. 2003, quoted in Saharso (2007).

31 BW 13/3091, Gesetz zur Änderung des Schulgesetzes, 14 April 2004. headscarf, the crucifix belongs to our Western culture, to our tradition and has here a high standing as a religious evidence of brotherly love, tolerance and human dignity [...]. We acknowledge the mandate of our federal constitution to educate our children according to Christian and Western cultural values. The state neutrality in our public schools may, unlike a Laic state, recognise religious expression, but only those that don't contravene the embedded human rights'. ${ }^{32}$

Attempts to dispute the Christian-Occidental legislation of the five federal states failed (Henkes \& Kneip, 2008). Federal courts have argued that teacher-nuns, who are few, should be considered 'historical exceptions' that do not constitute a systematic discrimination of Islamic religious communities (Berghahn \& Rostock, 2009).

\subsection{Laic Model}

Berlin is a paradigmatic example of the 'laic' legislation, which has also been passed in Lower Saxony and Bremen. Their laws ban all personal expressions of political, religious and philosophical beliefs for reasons of public neutrality (Bremen and Berlin) or in light of the state's educational mandate (Lower Saxony).

In Berlin, deputies of the governing parties SPD and PDS/Die Linke, as well as the oppositional parties the FDP and Greens, all argued that the privatisation of all personal religious affiliations by teachers was the best guarantee to safeguard religious freedom and religious peace. Concerns about Islamic radicalism also shaped the debate.

32 BW 13/62, 4 February 2004.

Table 1. Policy regimes on headscarves in Germany (from: Lettinga, 2011).

\begin{tabular}{|c|c|c|c|}
\hline Laic & Christian Occidental & Case by case & Case by case \\
\hline Neutrally formulated ban & $\begin{array}{l}\text { Specific ban: exemption } \\
\text { for Christian -Occidental } \\
\text { cultural traditions }\end{array}$ & $\begin{array}{l}\text { Specific ban rejected: } \\
\text { context specific approach }\end{array}$ & $\begin{array}{l}\text { No ban proposed: context } \\
\text { specific approach }\end{array}$ \\
\hline Bremen 2005 CDU-SPD* & $\begin{array}{l}\text { Baden-Württemberg } 2004 \\
\text { CDU-FDP }\end{array}$ & $\begin{array}{l}\text { Rhineland-Palatinate } 2005 \\
\text { SPD-FDP }\end{array}$ & Saxony \\
\hline $\begin{array}{l}\text { Lower-Saxony } 2004 \text { CDU- } \\
\text { FDP }\end{array}$ & Bavaria 2004 CSU & $\begin{array}{l}\text { Schleswig-Holstein } 2004 \\
\text { SPD-Greens }\end{array}$ & $\begin{array}{l}\text { Mecklenburg- } \\
\text { Vorpommern }\end{array}$ \\
\hline \multirow[t]{3}{*}{$\begin{array}{l}\text { Berlin } 2005 \text { SPD-PDS/Die } \\
\text { Linke }\end{array}$} & Hessen 2004 CDU & $\begin{array}{l}\text { Hamburg } 2004 \text { CDU-FDP- } \\
\text { PRO }\end{array}$ & Thuringia \\
\hline & $\begin{array}{l}\text { North Rhine Westphalia } \\
2006 \text { CDU-FDP }\end{array}$ & $\begin{array}{l}\text { Brandenburg } 2003 \text { SPD- } \\
\text { CDU }\end{array}$ & Saxony-Anhalt \\
\hline & Saarland 2004 CDU & & \\
\hline
\end{tabular}

Notes: * Parties denote government; The neutrality law of Hessen concerns both teachers and regular civil servants. The neutrality law of Berlin concerns teachers and civil servants, as well as other public functions in the judiciary and the police. In Berlin, BadenWürttemberg and Hessen teacher-trainees may, 'in principle', express personal religious affiliations. The law of Baden-Württemberg also forbids the wearing of headscarves for personnel working in kindergartens. The law of Berlin allows this 'in principle', unless parents complain. 
The SPD, Greens and FDP agreed that the state had to prevent the intrusion of Islamism in public institutions by banning politicized signs and symbols. ${ }^{33}$ Most parties also considered a ban necessary to liberate young Muslim girls from patriarchal pressure ${ }^{34}$, but believed a ban on religious signs for teachers only was enough. ${ }^{35}$

\subsection{Non-Regulation}

Finally, eight states continue a case-by-case approach. In Schleswig-Holstein, Rhineland Palatinate and Hamburg teachers are allowed to express their personal religious beliefs unless there is evidence that they disrespect the religious views of pupils or parents, or if the school's peace is endangered (e.g. when parents object). Jochen Hartloff of the SPD faction argued: 'We have a separation between state and church. This is traditionally regulated differently than in France. We too have a separation, but the boundaries are much more blurred in light of our Occidental-Christian background.' ${ }^{36}$ The CDU proposed to ban headscarves for schoolteachers, but the SPD and FDP rejected the CDU's proposal. ${ }^{37}$ Five of the 'tolerant' states are former Eastern German states. In these states there is no regulation, because there were no headscarf conflicts as Muslim migrants form a small minority whose presence has not (yet) stirred debates about the nation's multicultural outlook.

In Germany women's organisations were not invited to any policy debate, turning headscarves into a migrant problem. Several women of Turkish origin were invited as authorities on Islam. Seyran Ateş (SPD) was invited to a public hearing in Baden-Württemberg ${ }^{38}$ and (the Kurdish) Necla Kelek and (the Alevi) Serap Cileli to a hearing in Rhineland Palatinate. ${ }^{39}$ These women are well-known critics of Islam. In their view the headscarf is not a religious duty, but a patriarchal tradition used by Islamic fundamentalists. They found support from, amongst others, well-known feminist Alice Schwarzer who compared the headscarf to the yellow star that Jews were forced to wear during the Nazi regime. Women who wore the headscarf were largely excluded from the debate. Lacking institutional venues,

33 B .15/36, 25 September 2003; B. 17/58, 28 October 2004; B.15/45, 19 February 2004.

${ }^{34}$ B .15/45, 19 February 2004; B. 15/62, 20 January 2005.

35 Eventually, Berlin established a working group 'Islam und der Schule' (Islam and the School) to engage with communities, families and 'Islam experts' (such as outspoken anti-headscarf protagonists Necla Kelek and Seyran Ateş) on conflicts related to gender and Islam. B. 16/11258, 28 September 2007.

${ }^{36}$ B. 15/53, 17 January 2005.

${ }^{37}$ RP 14/91 17 March 2005: 6094.

38 Protokoll der 26. Sitzung des Ausschusses für Schule, Jugend und Sport vom 12. März 2004.

39 32. Sitzung des Ausschuss für Bildung und Jugend. 29. Sitzung des Rechtsausschusses am 11 Juli 2005 Gemeinsame offentliche Sitzung. in January 2004 various Muslim women went demonstrating in Berlin against the ban in civil service. ${ }^{40} \mathrm{New}$ Muslim women's associations emerged, like the Initiative for self-determination ('Initiative für Selbstbestimmung'), which critiqued the stereotypical image of veiled women as oppressed victims or fundamentalists. ${ }^{41}$ In 2007, several women created the first national Muslim women's organisation, the Action Alliance ('Aktionsbündnis') (Oestreich, 2004). The Green and the Social Democrat parties supported the Alliance and organised a conference on Islam and feminism. ${ }^{42}$ Women wearing headscarves found allies in Commissioners of Integration, such as former Berlin Commissioner for Foreigners Barbara John (CDU), who argued in a hearing on headscarves for the parliament in Rhineland Palatinate that a ban hampers Muslim women's' emancipation because it restricts their access to the labour market. She also argued that a ban would pressure women to choose the side of their communities and to surrender to gender-oppressive community norms rather than criticize these. ${ }^{43}$ Together with Berlin Integration Officer Marieluise Beck (Greens) and the CDU politician Rita Süssmuth, ${ }^{44}$ John launched a petition in 2003 to argue against bans on headscarves and for solidarity with all those who fight Islamism, including those with headscarves (BPB, 2003). The appeal was signed by more than seventy publicly known women.

Similar to France and the Netherlands, some German deputies in the Federal Parliament have started to ask for a full ban on the Islamic face cover in public, such as Lale Akgün of the SPD fraction did in 2010. Her party, however, objected to legislation. SPD expert on interior affairs Dieter Wiefelspütz argued that soft measures are a better way to develop an 'Enlightenment Islam'. The Greens also objected, labelling such laws as symbolic politics that do not target the heart of the problem. The FDP and CDU argued that a ban on headscarves offered already sufficient grounds to expel pupils with face veils (Deutsche Welle, 2010). So far, no legislation has been proposed.

40 The demonstration took place on January 17, 2004. It was organised by IMbus (Initiative Berliner Muslims).

41 The Initiative für Selbstbestimmung ('Initiative for Selfdetermination') wrote various open letters, amongst others to Ekin Deligöz, Lale Akgün and Mehmet Daimagüler, who had asked Muslim women to remove their headscarves in the weekly 'Bild am Sonntag' (14 October 2006).

42 The conference 'Frauen Power im Islam' took place in Cologne in 2008. See Naggar (2008).

43 32. Sitzung des Ausschuss für Bildung und Jugend/29. Sitzung des Rechtssausschusses, Gemeinsame öffentliche Sitzung,11 July 2005.

44 Rita Süssmuth was Minister of Family Affairs from 1985 to 1988. Barbara John was the Commissioner for foreigners ('Ausländerbeauftragte') to the Berlin Government from 1981 to 2003. 


\section{Gender and Nation}

Since about the turn of the century, in all three countries the headscarf became more often associated with Islamic fundamentalism and interpreted as a symbol of gender inequality within Islam. How to explain this convergence?

While several headscarf cases have been brought to the European Court of Human rights (ECtHR) the convergence is not explained by a growing European influence. In fact, the ECtHR grants member states a broad discretionary scope to interpret the protection of the freedom of thought, conscience and religion in the light of their national traditions (Berghahn, 2011). Legislators in France and Germany explicitly referred to this socalled 'margin of appreciation' to adjust the scope of religious freedom to these historical traditions (Bowen, 2007; Lettinga, 2011). The ECtHR thus paradoxically creates opportunities for politicians to reaffirm and extend institutional logics of historical state-church relations (in France) or change these in a direction that actually restricts religious freedom (in Germany).

We considered whether this focus on gender inequality could be attributed to an increasing influence of the (institutionalized) women's movement on the parliamentary debates. In France indeed parts of the women's movement organized to demand a ban but their statements were in line with the majority of politicians' views. It may be that they got a voice because of a selective invitation policy on the part of the hearing committees. There were alternative feminist voices, but they were not invited and unlike Germany, there were no women's voices within the country's gender machinery or migration departments that opposed a ban from a female autonomy frame. In the Netherlands the headscarf was so broadly accepted that the women's movement felt no need to mobilize pro or contra and thus did not raise its voice. Therefore we want to suggest that the change in framing is explained by a different development.

Wearing a headscarf became associated with a radical political Islam threatening European values at a time when Islamic violence manifested itself (inter) nationally. In France and the Netherlands populist antiimmigrant right wing parties became strong political forces. In the Netherlands, the LPF became in 2002, hence one year after $9 / 11$, in one blow the second largest party in the country. These parties framed the headscarf not as an isolated religious issue, but as symbolic for Islamic immigrants living in 'parallel societies' unwilling to integrate and respect the basic values of the national communities. The headscarf was a vehicle to express concerns about immigration and national identity. We interpret the salience that gender equality gained as a diagnostic frame in this period as part and parcel of this symbolic politics. The gender card was drawn to demarcate the boundary between the civilized Westerner and the uncivilized and illiberal Islamic outsider. Yet, in 2004, the year that France adopted a law to ban ostentatious religious symbols, the Netherlands adopted a rule granting women the right to wear a headscarf. In Germany several states adopted laws in that period, but there is no consistent pattern (see Table 1). Despite populist rhetoric shaping the saliency and (converging) diagnostic framing of the debate, the actual regulation of the headscarf thus appears to be more determined by established national citizenship and state-religion relations (Hadj-Abdou et al., 2011).

\section{Conclusion}

We expected France and Germany to have more restrictive regulation than the Netherlands. France and the Netherlands kept to our expectations, but Germany only to a certain extent. While France prohibits religious dress in public schools and public functions, the Netherlands and Germany tolerate headscarves for pupils. Public school teachers' headscarves are forbidden in eight German states, but (conditionally) allowed in eight other states and also allowed in the Netherlands. In the latter contry all civil servants have a right to wear a headscarf except for court personnel and uniformed police officers. In Germany two states have passed bans on religious expressions for not only teachers but also civil servants. France clearly has the most restrictive regulation, then follows Germany, and the Netherlands has the most tolerant regulation.

Our data shows that national histories of nation building and old political cleavages are resounding in the framing of the headscarf. We do not think therefore that citizenship and state-church models are but an invention of scholars or politicians. These national traditions are however internally more diversified than the idea of national models might suggest. Against their supposed aversion to religion in the public sphere, the French for a while allowed headscarves in public schools. This diversification also offers an explanation for the German case. The German state has a tradition of openness to religion, but prioritizes Christianity over minority religions, except Judaism that is now conceived as part of the Germany's Western heritage. The southern German states focused on Germany's exclusionary tradition and defined the nation as a Christian-Occidental nation. Other states stressed the nation's traditional openness to religion and some other leftwing states reacted against the idea of the nation being defined by Christianity and opted for a strict separation of state and church. The cases thus illustrate that politicians may select certain aspects of their national institutional traditions, thereby affirming or combating them, but even if they oppose them they do not stand outside of them. Yet national models suggest too much rigidity. It is better perhaps to speak as John Bowen suggests in terms of schemas: 'categories, images, propositions, often deeply psychologically embedded in actors' minds, that may coexist without nec- 
essarily being consistent and that may be weighed differently from one moment to another' (Bowen, 2012, p. 354). Power constellations and the coalitions' different actors enter into matter for how this discursive battle plays out in actual policy formation processes.

Lastly, what does the framing of the headscarf tell us about the social inclusion of Islamic women? In France, Islamic women can be full citizens of the Republic, and increasingly so, only if they take off their headscarf. Otherwise they are paradoxically perceived as both victims and aggressors of a segregationist Islamic community, which is unwilling to blend in with the broad French political community. In the Netherlands the discourse on headscarves became more intolerant over the years, but regulation is comparatively tolerant and in that sense Islamic women can be members of society with inclusion of their headscarves. In the southern German states, women wearing headscarves are excluded from the nation that is defined as a Christian-Occidental nation. In the other German states that follow either a laic or a case-by-case approach, women wearing a headscarf are seen by politicians as victims of their communities, but more often as representatives of a political Islam who must constantly prove their loyalty to the German nation. In all three countries the framing of headscarves as a symbol of gender inequality within Islam gained in strength when polarization around Islam increased and anti-immigrant populist parties came up. Coalition framing emerged between feminist and populist politicians, but also frame cooptation by populists acting as champions of women's right. Some feminists have started to organize across religious and secular boundaries to oppose the instrumentalization of women's rights against Islam. But until these alliances become stronger and more influential, headscarf-wearing and particularly veiled women are still largely excluded from the European national imaginary.

\section{Acknowledgments}

We would like to thank Marcie Hale of University of California, Los Angeles, for her careful editing of this article.

\section{Conflict of Interests}

The authors declare no conflict of interests.

\section{References}

Altinordu, A. (2004). The Meaning(s) of the Headscarf: The German 'Kopftuchstreit'. Paper presented at the Annual Meeting of the American Sociological Association, 14 August 2004, San Fransisco, USA.

Asad, T. (2006). Trying to understand French secularism. In H. de Vries (Ed.), Political theologies. New York: Fordham University Press.

Berghahn, S. (2008). Kopftuchfalle für Gericht. In S. Berghahn, U. Lange, \& U. Schulz, Rechtshandbuch für
Frauen- und Gleichstellungsbeauftragte. Hamburg: DasHofer Verlag.

Berghahn, S. (2011). Legal Regulations. Responses to the Muslim headscarf in Europe. In S. Rosenberger \& B. Sauer (Eds.), Politics, Religion and Gender: Framing and Regulating the Veil (pp. 97-115). London and New York: Routledge.

Berghahn, S., \& Rostock, P. (eds.) (2009). Der Stoff, aus dem Konflikte sind. Debatten um das Kopftuch in Deutschland, Österreich und der Schweiz. Bielefeld: Transcript.

Bonjour, S. (2010). Recht, partijpolitiek en omgang met de 'Ander': Waarom het Nederlands beleid inzake inburgering in het buitenland strenger is dan dat van Frankrijk. (Law, party politics and the contact with the 'Other': Why the Dutch policy on civic integration abroad is stricter than that of France). Migrantenstudies, 26(4), 305-322.

Bouteldja, H. (2007). De la cérémonie de dévoilement à Alger (1958) a NPNS: l'instrumentalisation coloniale et néo-coloniale de la cause des femmes. Retrieved from http://Imsi.net/article.php3?id_article $=320$

Bowen, J. R. (2007). Why the French don't like headscarves. Islam, the state, and the public space. Princeton and Oxford: Princeton University Press.

Bowen, J. R. (2012). Working schemas and normative models in French governance of Islam. Comparative European Politics, 10(3), 354-368.

BPB. (2003). Religiöse Vielfalt statt Zwangsemancipation! Aufruf wider eine Lex Kopftuch. Retrieved from http://www.bpb.de/themen/XUDYWD.html

Brubaker, R. (1992). Citizenship and nationhood in France and Germany. London: Harvard University Press.

Castles, S. (1995). How nation states respond to immigration and ethnic diversity. New Community, 21(3), 293-308.

Castles, S., \& Miller, M. J. (2011). The age of migration. International population movements in the modern world ( $4^{\text {th }}$ ed.). New York: Palgrave Macmillan.

Chirac, J. (2003). Speech to the Senate, 17 December 2003.

Chouder, I., Latreche, M., \& Tévanian, P. (2008). Les villes voilées parlent. Paris: la Fabrique.

Deutsche Welle. (2010). Burka-Verbot in Deutschland? Deutsche Welle. Retrieved from http://www.dw. de/burkaverbot-in-deutschland/a-5525223

Ferrari, A., \& Pastorelli, S. (Eds.) (2013). The burqa affair across Europe: Between public and private space. Farnham: Ashgate Publishing.

Fetzer, J. S., \& Soper, C. (2005). Muslims and the state in Britain, France, and Germany. Cambridge: Cambridge University Press.

Foblets, M. C., \& Alidadi, K. (Eds.) (2013). Religare. Religious diversity and secular models in Europe. Innovative approaches to law and policy. Summary Report on the Religare project. Retrieved from http://www.religareproject.eu/content/finalsummary-report-religare-project 
Hadj-Abdou, L., Rosenberger, S., Saharso, S., \& Siim, B. (2011). The limits of populism. Accommodative headscarf policies in Austria, Denmark, and the Netherlands. In S. Rosenberger \& B. Sauer (Eds.), Politics, Religion and Gender: Framing and Regulating the Veil (pp. 132-149). London and New York: Routledge.

Henkes, C., \& Kneip, S. (2008). Laizismus durch die Hintertur. Der Kopftuchstreit zwischen Parlamenten und Gerichten. In WZB-mitteilungen. Berlin: Wissenschaft Zentrum Berlin.

Joppke, C. (2001). Limits of restricting Islam: The French burqa law of 2010. Paper presented to the Migration Studies Unit of the London School of Economics, 25 January 2011.

Joppke, C. (2007). Beyond national models: civic integration policies for immigrants in Western Europe. West European Politics, 30(1), 1-22.

Koenig, M. (2007). Europeanising the governance of religious diversity: An institutionalist account of Muslim struggles for public recognition. Journal of Ethnic and Migration Studies, 33(6), 911-932.

Koopmans, R., Statham, P, Giugni, M., \& Passy, F. (2005). Contested citizenship. Immigration and cultural diversity in Europe. London: University of Minnesota Press.

Laborde, C. (2008). Critical Republicanism. The Hijab Controversy and Political Philosophy. New York: Oxford University Press.

Lettinga, D. N. (2011). Framing the hijab. The governance of intersecting religious, ethnic and gender differences in France, the Netherlands and Germany. Ridderkerk: Ridderprint.

Michalowski, I. (2011). Required to assimilate? The content of citizenship tests in five countries. Citizenship Studies, 15(6-7), 749-768.

Modood, T., \& Kastoryano, R. (2006). Secularism and the accommodation of Muslims in Europe. In $\mathrm{T}$. Modood, A. Triandafyllidou, \& R. Zapata-Barrero (Eds.), Multiculturalism, Muslims and citizenship: $A$
European approach. New York: Routledge.

Naggar, M. (2008). Kopfstoff für die Emanzipation. TAZ.de. 14 July 2008.

Oestreich, H. (2004). Der Kopftuch-Streit. Das Abendland und ein Quadratmeter Islam. Frankfurt am Main: Brandes und Apsel.

Rochefort, F. (2002). Foulard, Genre et Laicité en 1989. Vigtième Siècle Revue d'Histoire, 75, 145-156.

Saharso, S. (2007). Headscarves: a comparison of public thought and public policy in Germany and the Netherlands. Critical Review of International Social and Political Philosophy, 10(4), 513-530.

Schön, D. A., \& Rein, M. (1995). Frame reflection: toward the resolution of intractable policy controversies. New York: Basic Books.

Scott, J. W. (2007). The politics of the veil. Princeton and Oxford: Princeton University Press.

Silverman, M. (1992). Deconstructing the nation: immigration, racism and citizenship in modern France. London: Routledge.

Stasi, B. (2003). Commission de réflexion sur l'application du principe de laïcité dans la République: rapport au Président de la République. Paris: Présidence de la République.

Sarkozy, N. (2009). Déclaration de m. Le Président de la République devant le Parlement réuni en congrès. Versailles, France, 22 June 2009, p. 5.

Verloo, M. (2005). Mainstreaming gender equality in Europe. A critical frame analysis approach. The Greek Review of Social Research, 117, 11-34.

Vermeulen, B. P., Doorn-Harder, N., Loenen, T., Leemhuis, F., Ghaly, M. M, van Bommel, A., \& Loof, J. P. (2006). Overwegingen bij een boerka verbod. Zienswijze van de deskundigen inzake een verbod op gezichtsbedekkende kleding. (Considerations on a burqa ban. Viewpoint of experts regarding a ban on face-covering clothing). Retrieved from https://openaccess.leidenuniv.nl/bitstream/handle /1887/13377/7\%20niqab_rapport.pdf?sequence=1

\section{About the Authors}

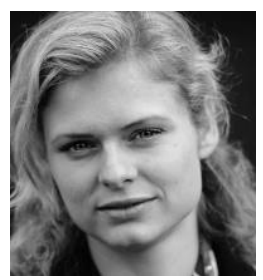

\section{Dr. Doutje Lettinga}

Doutje Lettinga has a doctorate in Sociology at the VU University Amsterdam (2011) and a double Master in history and political science at the University of Amsterdam. Her research interests include international relations, migration, gender, multiculturalism, sociology of religion, anti-discrimination and human rights. She currently works as a research fellow for the Strategic Studies Project of Amnesty International Netherlands.

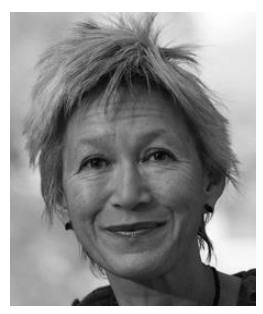

\section{Dr. Sawitri Saharso}

Sawitri Saharso is Professor of Intercultural Governance at the School of Management and Governance of the University of Twente (Enschede, The Netherlands) and Associate Professor at the Department of Sociology of the VU University Amsterdam. She is interested in questions of citizenship, social diversity and inclusion within a European comparative perspective. She is Editor-in-Chief of Comparative Migration Studies. 